\title{
Corrigendum: Modulating protein activity using tethered ligands with mutually exclusive binding sites
}

\author{
Alberto Schena, Rudolf Griss \& Kai Johnsson
}

Nature Communications 6:7830 doi: 10.1038/ncomms8830 (2015); Published 22 Jul 2015; Updated 15 Feb 2016

The original version of this article was published with an incorrect label for Fig. $4 \mathrm{c}$. The labels 'no tacrine' and ' $3 \mathrm{mM}$ tacrine' were associated with the incorrect fluorescence micrographs. The correct version of Fig. 4 appears below. 
a
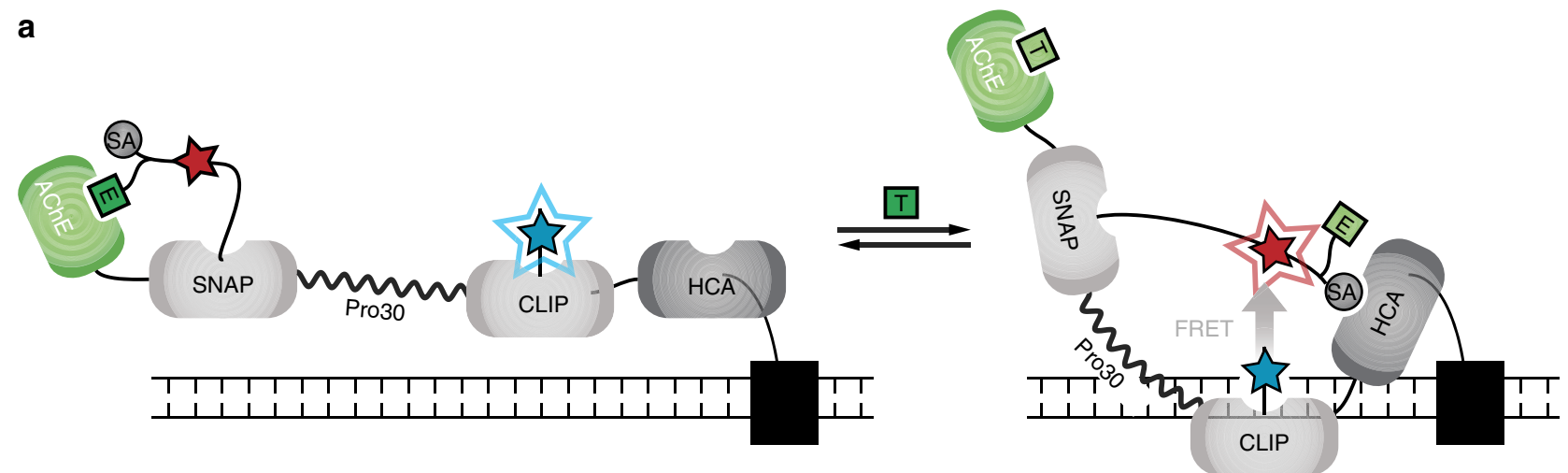

b

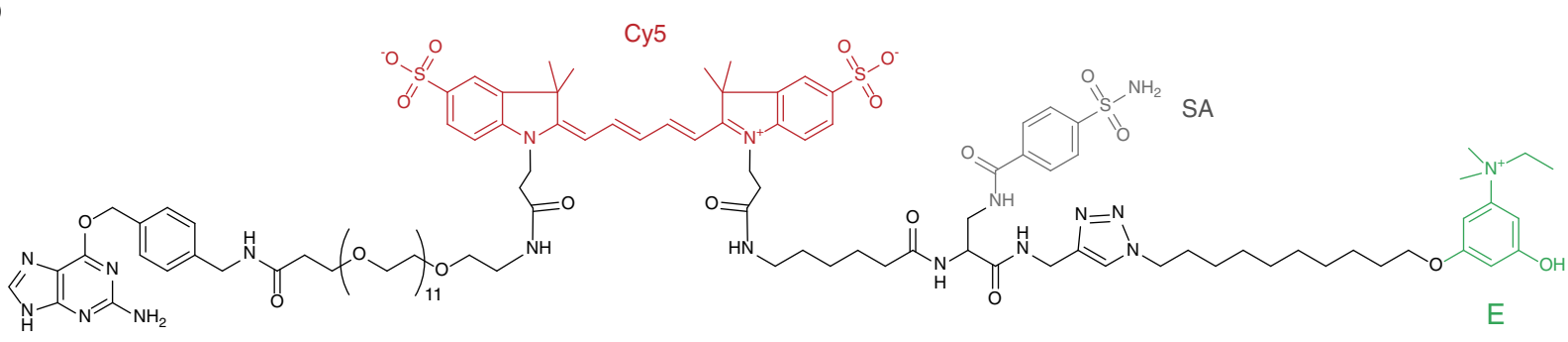

BG

BG-Cy5-SA/Edro

C

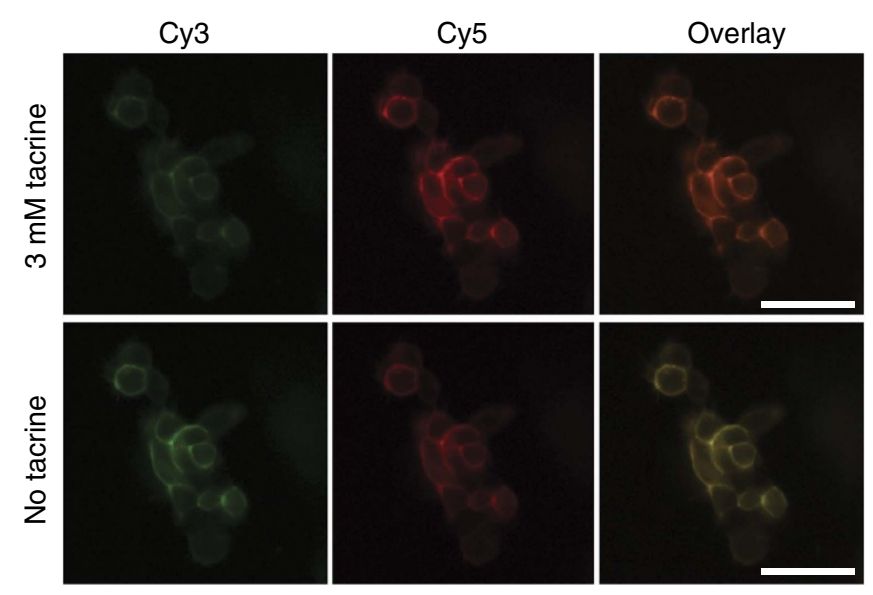

d
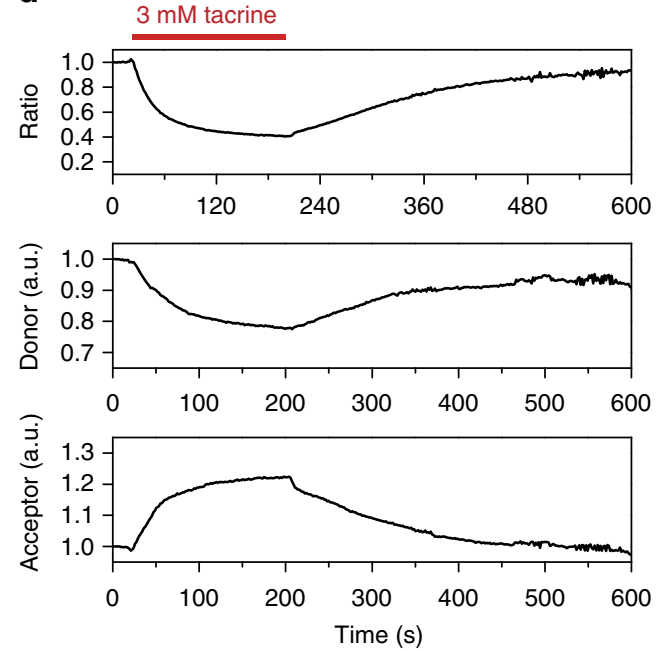

Figure 4

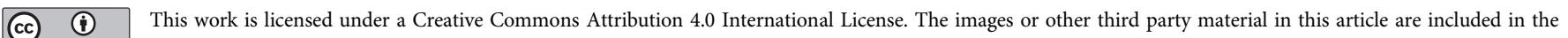
article's Creative Commons license, unless indicated otherwise in the credit line; if the material is not included under the Creative Commons license, users will need to obtain permission from the license holder to reproduce the material. To view a copy of this license, visit http://creativecommons.org/licenses/by/4.0/ 